\title{
Cooperative Acquisitions in the United States Versus a World Library ${ }^{1}$
}

I

I HAVE BEEN asked to represent the small college libraries in a discussion of the Boyd-MacLeish-Metcalf plan for cooperative acquisitions in the interest of national resources.

By this plan one copy of every book published anywhere in the world, which might conceivably be of interest to a research worker in America, shall be acquired by at least one research library in the United States. The books thus acquired shall be promptly cataloged and duly listed.

The modus operandi shall be as follows: each cooperating library shall assume responsibility for complete coverage in a given subject or area. The entire field of human knowledge (subdivided according to the L.C. or a similar classification) shall be apportioned out to the cooperating research libraries under a central steering committee. As a preliminary trial, however, the acquisitions shall be limited to publications in the Latin alphabet.

\section{II}

It is my opinion that small college libraries can have no direct share in this plan. I find two major obstacles to their participation:

(I) Any area of knowledge in which a small college could assume responsibility would be infinitesimal. A nationwide organization of pin-points of knowledge would be

1 Paper presented at the Conference of Eastern
College Librarians, Columbia University, Nov. 30, r 946 . unmanageable. Small colleges may have special collections, but such collections are only hobbies-they are scarcely even drops in the ocean of knowledge. Haverford, for instance, has Quakeriana but has never been able to acquire everything published. In a field of this sort, moreover, the collector's chief effort is expended on unprinted or irregularly printed materials, not in the book trade.

(2) The small college library cannot expand indefinitely. A small college is one whose enrolment is limited to a les-thanaverage total. Consequently, the size of its library is limited; and for this as well as for. pedagogical reasons the small college library must be wholly selective. For instance, Haverford College, limited to four hundred students, may not reasonably go beyond a library of two hundred thousand volumes. Beyond that figure we begin to discard at the other end. There is no room in such a librory for unlimited expansion in any field of research. The budget will not allow it; the faculty would not approve it.

\section{III}

I turn now to general criticism of the whole plan. In this, I represent an individualistic view which is characteristic (I believe) of the small college. Having devoted my life (in a humble way) to pure scholarship, I am in a position to criticize the plan as a consumer.

In my opinion the whole scheme is impractical and fundamentally unsound. You cannot devise a system which will take the place of individual initiative.

The proposed plan is a will-o'-the-wisp which has appeared in many forms. Someone is always trying to organize the future, 
to anticipate history. For instance, historians (in moments of desperation) have been known to say: "Let's preserve everything, so that there will be no more controversy in the future!" But God forbid that we have a world of Morgenthau diaries: there would not be even standing room for the living.

Text-critics have been known to say: "Let's collate all the manuscripts and all the editions, and produce a definitive text, never to be questioned!" But no problem involving human judgment is ever definitively settled.

Librarians have been known to say: "Let's all get together and catalog all the manuscripts in the world, once and for all!" But thesalibrarians did not know that that is more than all the competent scholars in the world could do in a hundred years.

So now other librarians say: "Let's acquire all the books in advance; then we won't be pestered by these scholars asking us for something we haven't got." Alas, scholars are as ingenious as the devil, and can think of more things than were ever dreamed of in the librarian's philosophy.

\section{Two Separate Problems}

But I am not denying that there is a problem. Actually, there are two problems, and I am not sure that they are clearly distinguishable. They are: (I) how to supply American scholars with as many books as possible here at home and (2) how most conveniently to guarantee one copy of every book in the world to research workers. To the second of these problems (which is by far the more important) the committee added "in America." This qualification is pertinent to the first problem, but not to the second. I deplore the narrow nationalistic point of view. Without remitting our efforts to supply as many foreign books as possible to American libraries, let us strive in the larger field to guarantee one copy of every book in the world to the research workers of the world! As to how this may be done, I shall presently offer some sugges tions.

Returning to the proposed plan for cooperative acquisitions by American libraries, is it not a whole generation behind the times? In a world which is rapidly shrinking geographically, would it not be cheaper and surer and quicker to send the scholar to the books he needs than to try to bring all the books in the world to the scholar before he needs them? Mohammed (in his day) was wiser-he went to the mountain.

Still, many voices cry out in consternation: "How can we keep up with the procession?" This is an old problem, now grown acute. It is not confined to the library field. It prevades all modern life and thought-education, scholarship, human knowledge in general.

We are faced with an intellectual world expanding at an astronomical rate. The areas covered by modern learning are so diverse and so vast that a single individual can hardly even survey them-let alone encompass them (a feat which Aristotle was the last man to achieve). The activities of the human mind are unbounded-and growing more so every day and hour!

\section{Books in All Languages}

As a first step, then, toward solving this problem, we are offered a tentative acquisition of books in the Latin alphabet-a test case which so dodges the real difficulties as to be practically useless. Scholarship knows no boundaries of alphabet. Only when we get books on every subject in Russian, Hebrew, Arabic, Greek, Turkish, Armenian, Hindustani, and what not, will we approach our goal. I am aware of the fact that we are promised them later, but success in ac- 
quiring our own kind of books is no guarantee of success in the far more difficult field.

Even in the case of books printed in the one alphabet legible to $u s$, I doubt whether we will ever get half the guarantors we need to cover all knowledge. Even universities have other demands on their income. And as for the books in strange alphabets, I have a feeling that we will never get them.

Even when we get books from all countries (irrespective of alphabet), we are promised only those "which may conceivably be of interest to a research worker in America." And who is to decide what will be of interest to research workers? Librarians are not competent to do so. The Army (and other government departments) are not competent to do so-as proved by the melancholy results of the current foreign acquisitions project. Never again, after this experience, will I sign a blank check to the order of a cooperative purchasing committee. Even the scholars who are going to use the books are not competent to do so: they can hardly be expected to foresee every future development and trend of human thought.

These selected books, temporarily to be chosen from those which have passed the nationality test, will then be scattered all over the land, in accordance with an approved classification of knowledge. So then - provided the chain has no weak links (local failure of funds, changes of policy, etc.) -the scholar will have the satisfaction of knowing that the books he wants are here, but (alas) distributed all over the United States from San Francisco to Boston. Surely a single location would be far more sensible.

But even so, this would merely be one step in a system of nationalistic duplication, by which all books from other countries would be brought to our country, and all our books would be taken to each of many other countries, and so on ad infinitum-a clumsy and ponderous method, if ever there was one!

\section{World Library}

Omitting the minor problem of how to acquire as many good books as possible for the United States, there can be but one logical answer to the major problem (how to guarantee one copy of every book in the world to research workers-and I add, "of the world"). The answer is: a United Nations library! One world, one library! Wherever the UN or UNESCO shall decide (be it in Europe, Asia, Africa, or America-but preferably not in America, where the cost of living is too high), let us create a new Alexandria, to which each cultural unit shall contribute its whole output of printed matter: a haven for scholars, and a paradise for librarians.

I envisage not a single library building, but a city of libraries. The solution is analogous to that of the language problem: many mother tongues, but one international language. So each country will keep its national library, but will send one duplicate of every piece of printed matter to the international center. Starting with current publications, ways and means of supplying the older materials can be worked out.

The location should be in a dry and salubrious climate. Stratosphere travel to this one center will of course be easier than a series of visits to all or many of the national capitals of the world. I believe that each nation will be willing and anxious to contribute such a sample copy of its annual output of printed materials to the world library. 